УДК 343.963

DOI https://doi.org/10.32782/2409-4544/2020-1/19

О. Крикунов, Г. Денісова

\title{
Незмінність прокурора у кримінальному провадженні
}

Розглянуто правове забезпечення та наукові підходи до незмінності прокурора в кримінальному провадженні. Незмінність прокурора як правовий і функціональний ознака його статусу в кримінальному провадженні забезпечує його самостійність, ефективність i, разом 3 цим, підсилює його відповідальність. Системний аналіз норм Кримінального процесуального кодексу (КПК) України щодо участі прокурора в кримінальному провадженні вказує на існування значної кількості підстав для заміни прокурора, які вимагають конкретизації в частині оціночних понять. Окремі підстави для заміни прокурора носять дискреційний характер, що створює ризики помилок при їх застосуванні. Така підстава для заміни прокурора у кримінальному провадженні, як «інші поважні причини, які унеможливлюють участь прокурора в кримінальному провадженні» (ч. 3 ст. 37 КПК України) має повністю дискреційний характер. Тому для коректного правозастосування цю норму слід доповнити словосполученням «підтверджені конкретними фактами, які їх доводять». Період кримінального провадження, протягом якого прокурор має бути незмінним, розпочинається із моменту призначення прокурора як процесуального керівника досудовим розслідування окремою постановою, яка має виготовлятися на офіційному бланку і містити підпис керівника органу прокуратури. Правило про незмінність прокурора передбачає його участь як суді першої інстанції, так і у контрольних судових стадіях. Проте, виходячи із мотивів процесуальної економії, чинний КПК дозволяє участь вищестоящих прокурорів у судових засіданнях судів апеляційної, касаційної інстанцій. Норма про незмінність прокурора у кримінальному провадженні масово порушується через надмірно велике збільшення обсягу його роботи. Вирішення цієї проблеми ми вбачаємо у визначенні адекватних нормативів максимального навантаження на прокурора. Розповсюджена практика створення груп прокурорів тільки маскує, а не вирішує проблему їх перевантаженості і не забезпечує мету запровадження правила про незмінність прокурора у кримінальному провадженні.

Ключові слова: прокурор, незмінність, кримінальне провадження.

Постановка наукової проблеми та її значення. Наділений широкими повноваженнями у кримінальному провадженні, прокурор здійснює процесуальне керівництво досудовим розслідуванням та підтримує публічне обвинувачення, представляє інтереси держави та певних категорій потерпілих у судових провадженнях. Тому його об'єктивність та ефективність його процесуальної діяльності має не менше значення для досягнення завдань кримінального судочинства, як і незалежність судді. Чинний КПК України закріпив новітне положення про незмінність прокурора, але практика його правозастосування не стала одностайною через об'єктивні та суб'єктивні чинники. Крім того, ідея незмінності прокурора має бути розумно збалансована із низкою випадків для його вимушеної заміни. Слід вказати, що окремі підстави для заміни прокурора, передбачені у різних нормах чинного КПК, носять дискреційний характер, що створює складності, ризики помилок та зловживань при їх застосуванні. На нашу думку, вказані аргументи підтверджують актуальність обраного предмету дослідження.

Аналіз досліджень цієї проблеми. Окремі аспекти незмінності прокурора у кримінальному провадженні були досліджені у роботах А. В. Лапкіна, І. І. Шульгана, К. Сляднєвої, А. Михайлика, О. М. Бандурки, Є. М. Блажівського, Є. П. Бурдоль, В. М. Сакал, О. Толочка, М.В.Чорноусько, С. Махновець, А. Р. Туманянц Д. М. Говоруна, Д. С. Д'ячкова, Ю. Белоусова, В. Венгер, В. Мітько, А. Орлеан, В. Сущенка, В. Яворської, О. В. Сні, О. О. Шпак, М. В. Руденка.

Формулювання мети та завдань статті. Метою даної статті є спроба наукового аналізу припису про незміність прокурора у кримінальному процесі. Відповідно, завданнями роботи є: 3'ясування мети та функціонального навантаження, «меж» для забезпечення незмінності прокурора; визначення та оцінка сукупності підстав для заміни прокурора; встановлення причин недотримання норми про незмінність прокурора; формулювання науково обгрунтуваних пропозицій для удосконалення чинного КПК та практики його застосування.

Виклад основного матеріалу й обгрунтування отриманих результатів дослідження. Під час розробки законопроекту КПК України запровадження принципу незмінності прокурора було

() Крикунов О., Денісова Г., 2020 
визнано необхідним кроком у реформуванні вітчизняного кримінально-процесуального законодавства. Цей принцип, на думку експертів, мав полягати у покладенні повноважень зі здійснення нагляду на досудових стадіях і підтримання обвинувачення в суді на одного незмінного представника прокуратури. Така особа має призначатися незалежно від відомчої підслідності за кожною кримінальною справою 3 моменту іï порушення і здійснювати наглядово-обвинувальний супровід справи на всіх стадіях процесу; така службова особа може бути замінена лише на підставах та в порядку, передбачених відповідною нормою КПК. Логічним продовженням мала б стати стаття закону, яка передбачала б чіткий і вичерпний перелік підстав для заміни прокурора. Рішення про заміну прокурора повинне прийматися у формі постанови, в якій керівник відповідного підрозділу органів прокуратури зобов'язаний чітко обгрунтувати підстави такого рішення. На думку експертів, так можна буде забезпечити як гарантії незалежності прокурора, так i достатню гнучкість процесуальної форми. Остання дозволятиме дотримуватися розумного строку провадження та зберігатиме для прокурорів вищого рівня можливість виправляти помилки підлеглих працівників [1]. Висловлені побажання більшою мірою були враховані при формуванні проекту КПК. Його розробники у Пояснювальній записці до відповідного законопроекту акцентували на тому, що правило незамінності прокурора (тобто покладення функції 3 представництва обвинувачення у суді по конкретній справі на того прокурора, який здійснював нагляд за дотриманням законів органами, які проводили досудове розслідування) є однією із найбільш суттєвих новел у кримінальному процесі України [2]. Слід також згадати ще про деякі, на нашу думку, пов'язані новели проекту КПК закріплення за прокурором функції процесуального керівництва досудовим розслідуванням та відмову від інституту повернення справи на додаткове розслідування. Таким способом, вважаємо, автори проекту КПК прагнули посилити як повноваження, так і відповідальність прокурора як ключового суб' єкта оновленого кримінального процесу.

У КПК 2012 р. [3] законодавець зберіг таку константу кримінально-процесуальної діяльності, як незмінність складу суду, та закріпив нову - правило про незмінність прокурора. Воно випливає із змісту ч.1-2 ст. 37 КПК, згідно із якими прокурор (група прокурорів), який здійснюватиме повноваження прокурора у конкретному кримінальному провадженні, визначається керівником відповідного органу прокуратури після початку досудового розслідування і здійснює ці повноваження у кримінальному провадженні з його початку до завершення. Варто також згадати про ч. 2 ст. 77 КПК, згідно із якою попередня участь прокурора у цьому ж кримінальному провадженні в суді першої, апеляційної і касаційної інстанцій, як прокурора не є підставою для його відводу. Таким чином законодавець ще раз наголосив на участі одного прокурора на різних судових стадіях кримінального провадження.

Дослідники чинного КПК одностайно визнали користь від запровадження норми про незмінність прокурора, вказуючи на такі ii ефекти, як забезпечення обізнаності прокурора із фактичними обставинами кримінального правопорушення, володіння доказовою базою [4, с. 86; 5 , c. 517-518; 6, с.178; 7, с. 285], що є основою підвищення ефективності прокурора як суб'єкта підтримання публічного обвинувачення та представництва у суді [6, с. 178; 8, с.130; 9, с. 42] та посилення його відповідальності за посадову діяльність у кримінальному процесі [10, с. 143; 11, с. 6972; 12, с. 221]. Ми відзначені висновки поділяємо, оскільки, щонайменше, через затвердження (чи особисте складання) повідомлення про підозру, обвинувального акту чи клопотань, адресованих слідчому судді чи суду, у відповідного прокурора відбувається формування власного внутрішнього переконання у кримінальному провадженні, яке він буде обстоювати у судовому розгляді, оперуючи сукупністю обвинувальних доказів. Оскільки один і той же прокурор бере особисту участь у досудовому розслідуванні та у судових стадіях кримінального провадження, то це персоніфікує його відповідальність за результати роботи, досягнення завдань кримінального процесу.

Наступним аспектом нашої роботи є дослідження процесуальних меж дії правила про незмінність прокурора. Розпочнемо із аналіза суб'єкта, на якого це правило поширюється. Варто вказати, що визначення «прокурор - особа, яка обіймає посаду, передбачену ст. 15 Закону України «Про прокуратуру», та діє у межах своїх повноважень» (п. 15 ст. 3 КПК) охоплює тільки посадовий аспект діяльності прокурора. Правило незмінності застосовується як частина процесуального статусу конкретного прокурора, що призначений як процесуальний керівник досудовим розслідуванням (одноособово чи у складі групи прокурорів) керівником органу прокуратури (ч. 1 ст. 37 КПК). Ми вважаємо правильною думку А. Р. Туманянц, Д. М. Говорун про те, що керівник органу прокуратури не наділений повноваженнями щодо здійснення процесуального керівництва в силу своєї посади й може виконувати відповідні повноваження лише в разі призначення його процесуальним керівником 
у конкретному кримінальному провадженні [13 с. 256]. Виходячи із цієї точки зору, можна зробити висновок, що до керівника органу прокуратури не застосовується правило незамінності, якщо вищестоящий прокурор не призначив його процесуальним керівником досудового розслідування.

Період кримінального провадження, протягом якого прокурор має бути незмінним, законодавець визначає через вираз «з його початку до завершення» (ч. 2 ст. 37 КПК). Як свідчить аналіз наукових джерел, це положення закону тлумачиться не одностайно, $є$ і помилкові, на нашу думку, висновки. Зокрема, за висновком А. В. Лапкіна, І. І. Шульган, Д. С. Д’ячкова процесуальний керівник призначається 3 моменту внесення кримінального провадження до Єдиного реєстру досудових розслідувань $[4$, с. $85 ; 5$, с. $517 ; 14$, с. $15-16]$. Аналіз норм чинного КПК щодо порядку початку досудового розслідування та призначення прокурора для керівництва досудовим розслідуванням не підтверджує наведену точку зору. Хоча у КПК закріплено, що початком кримінального провадження є момент внесення відомостей про кримінальне правопорушення до Єдиного реєстру досудових розслідувань (п. 5 ст. 3 КПК), однак автори не враховують, що прокурор має бути призначений керівником органу прокуратури для участі у кримінальному провадженні. На це не впливає навіть та обставина, що прокурор особисто вже розпочав досудове розслідування відповідно до ч. 2 ст. 36, ч. 1 ст. 214 КПК.

Наш висновок підтверджений позицією ККС ВС, який визнав відсутність постанови про призначення прокурора для здійснення повноважень у кримінальному провадженні істотним порушенням норм КПК, які прямо вказують на це процесуальне рішення. Неналежно оформлена, не підписана постанова керівника органу прокуратури також не може вважатися рішенням про призначення прокурора. Рішення керівника відповідного органу прокуратури про визначення прокурора чи групи прокурорів у конкретному кримінальному провадженні $є$ процесуальним і має бути винесено у формі постанови, виготовляється на офіційному бланку та підписується службовою особою, яка прийняла відповідне процесуальне рішення, що передбачено ч. 6 ст. 110 КПК (постанова від 17.12.2019 р. у справі № 235/6337/18 [15]; постанова від 19.04. 2018 р. у справі № 754/7062/15-к, постанова від 19.09.2018 р. у справі № 761/20108/15-к) [16]

Відповідно до п. 2 розд. ІІ Порядку організації діяльності прокурорів і слідчих органів прокуратури у кримінальному провадженні, затв. наказом ГПУ 28 березня 2019 р. № 51, керівники прокуратур усіх рівнів, структурних підрозділів прокуратур усіх рівнів, їх перші заступники та заступники відповідно до розподілу обов'язків та у межах повноважень, передбачених КПК України невідкладно призначають прокурора у конкретному кримінальному провадженні. При визначенні прокурора у кримінальному провадженні обов'язково дотримуються рівномірного розподілу кримінальних проваджень 3 урахуванням таких критеріїв навантаження на прокурора: кількість кримінальних проваджень, у яких він здійснює повноваження прокурора самостійно та у складі групи прокурорів; досвід роботи, спеціалізація; кількість прокурорів у конкретному кримінальному провадженні; складність кримінальних проваджень, а саме багатоепізодність, суспільний резонанс, тяжкість злочину, місце скоєння злочину, необхідність проведення першочергових і невідкладних слідчих і процесуальних дій, обсяг слідчих (розшукових) і негласних слідчих (розшукових) дій, обсяг участі прокурора в розгляді слідчими суддями клопотань, скарг під час досудового розслідування, строки досудового розслідування та запобіжного заходу стосовно підозрюваного, необхідність підготовки документів для їх продовження, участь у продовженні строків, кількість учасників кримінального провадження; кількість слідчих, які здійснюють досудове розслідування у конкретному кримінальному провадженні, їхні досвід роботи та спеціалізація (п. 2 розд. IV вищевказаного Порядку) [17]. До Єдиного реєстру досудових розслідувань має бути невідкладно внесено відомості про прізвище, ім'я, по батькові прокурора, призначеного процесуальним керівником (п. 1 розд. 2 п.1 розд. 3 Положення про порядок ведення Єдиного реєстру досудових розслідувань, затв. Наказом ГПУ від 06.04.2016 р. № 139) [18].

Припинення дії норми про незмінність прокурора у кримінальному провадженні К. Слєдняєва пов'язує із закінченням періоду судового розгляду [6, с. 178: Із таким висновком підстав погодитися немає, адже після судового розгляду кримінальне провадження може продовжуватися.

I. I. Шульган висловив думку про те, що принцип незмінності прокурора у кримінальному провадженні діє аж до винесення судом остаточного рішення у ньому [5, с. 519] Але без уточнення про те, який саме суд має на увазі автор, цей висновок не може бути сприйнятий як коректний.

С. Кахновець вважає, що прокурор має бути незмінним до набрання судовим рішенням законної сили [12, с. 221 Позиція автора нечітка і тому незрозуміла, виходячи із змісту ст. 532 КПК, яка встановлює різний порядок набрання законної сили рішеннями судів різних інстанцій. 
На думку А. В.Лапкіна, Д.С. Д’ячкова незмінність прокурора має забезпечуватися до завершення судового провадження $[4$, с. $85 ; 14$, с. 16]. Із таким тлумаченням можна погодитися у комплексі із змістом п. 24 ст. 3 КПК, у якому вказано, що «судове провадження - кримінальне провадження у суді першої інстанції, яке включає підготовче судове провадження, судовий розгляд i ухвалення та проголошення судового рішення, провадження 3 перегляду судових рішень в апеляційному, касаційному порядку, а також за нововиявленими або виключними обставинами». Близьким є бачення М. В. Руденка, який поширює правило незмінності прокурора i на стадії перегляду судових рішень [19, с. 161].

За нашим висновком аналіз ч. 4 ст. 36, ч. 2 ст. 76 КПК дозволяє стверджувати що прокурор, який брав участь у суді першої інстанції, має повноваження на участь у подальших судових стадіях відповідного кримінального провадження. Разом із цим, законодавець дозволив у ч. 4 ст. 36 КПК участь у судовому провадженні з перегляду судових рішень у контрольних судових стадіях службових осіб органів прокуратури вищого рівня незалежно від їх участі в судовому провадженні. Слушною є думка К. Слєдняєвої, що це викликано особливістю організаційної структури органів прокуратури: $з$ огляду на можливості кадрового забезпечення, процесуальний супровід кримінального провадження на всіх стадіях одним і тим самим прокурором є досить сумнівним. Тому здебільшого участь у суді апеляційної та касаційної інстанцій бере прокурор прокуратури вищого рівня, що цілком припустимо [6, с. 178]. О. В. Сні вважає, що у випадку участі у судовому провадженні з перегляду судових рішень у контрольних судових стадіях службових осіб органів прокуратури вищого фактично відбувається не заміна прокурора у кримінальному провадженні, а субсидіарне здійснення прокурором вищого рівня повноважень прокурора у конкретному кримінальному провадженні, що, як видається, не потребує офіційної процедури заміни (усунення) попереднього прокурора [20, с. 297]. 3 наведеним $є$ підстави частково погодитися у висновку, що цей випадок заміни прокурора вищестоящою посадовою особою органів прокуратури не можна вважати усуненням підлеглого прокурора. Однак належна фіксація рішення про призначення вищестоящого прокурора для участі у контрольних судових стадіях є необхідною, зважаючи на наведені вище позиції ККС ВС.

Розглянемо передбачені у чинному КПК підстави для заміни прокурора, що є винятком із правила про незмінність прокурора. Аналіз змісту ч. $2-5$ ст. 36, ч.3 ст. 313, ч. 2 ст. 341 КПК дає підстави для визначення широкого, фактично невизначеного кола підстав для заміни прокурора. Зокрема, О.В. Єні, А.В. Лапкін, узагальнивши чинний КПК, встановили, що до підстав заміни прокурора законодавець відніс: 1) задоволення заяви про його відвід (ч. 3 ст. 37 КПК)*; 2) тяжка хвороба (ч. 3 ст. 37 КПК); 3) звільнення з органу прокуратури (ч. 3 ст. 37 КПК); 4) участь службових осіб органів прокуратури вищого рівня у судовому провадженні 3 перегляду судових рішень в апеляційному чи касаційному порядку, за нововиявленими або виключними обставинами (ч. 4 ст. 36 КПК); 5) доручення Генерального прокурора України, керівника регіональної прокуратури, їх перших заступників та заступників здійснювати подальше досудове розслідування кримінального правопорушення іншому органу досудового розслідування (за винятком підслідності НАБУ), у тому числі слідчому підрозділу вищого рівня в межах одного органу, у разі неефективного досудового розслідування (ч. 5 ст. 36 КПК); 6) покладення керівником органу прокуратури його повноважень на іншого прокурора цього органу прокуратури через неефективне здійснення прокурором нагляду за дотриманням законів під час проведення досудового розслідування у виняткових випадках (ч. 3 ст. 37 КПК)**; 7) заміна одного прокурора на іншого з числа службових осіб органів прокуратури того ж рівня в досудовому провадженні, де було прийнято або вчинено незаконне рішення, дія чи бездіяльність у разі скасування рішення або визнання незаконними вчинених дії чи бездіяльності прокурора (ч. 3 ст. 313 КПК); 8) усунення від участі в судовому розгляді прокурора у разі відмови у погодженні обвинувального акта із зміненим обвинуваченням, клопотання про висунення додаткового обвинувачення або постанови про відмову від підтримання державного обвинувачення 3 боку прокурора вищого рівня (ч. 2 ст. 341 КПК); 9) інші поважні причини, що унеможливлюють участь прокурора у кримінальному провадженні (ч. 3 ст. 37 КПК) [4, с. 86; 20, с. 293].

3 приводу окремих наведених вище підстав у наукових роботах нами виявлено тези, які мають дискусійний характер. Зокрема, Д. С. Д'ячков висловив міркування про те, що сумніви в аспекті забезпечення принципу незмінності викликає заміна прокурора-процесуального керівника у разі

\footnotetext{
* Див.: Денісова Г. В., Крикунов О. В. Підстави для відводу прокурора у кримінальному провадженні / Г.В.Денісова, О. В. Крикунов // Наук. вісник Херсонського держ. університету. Серія «Юридичні науки». - 2014. - Вип. 2, т. 4. - С. $80-85$.

**Див.: Крикунов О. В., Денісова Г. В. Заміна прокурора через неефективне здійснення нагляду за дотриманням законів під час досудового розслідування / О.В. Крикунов, Г.В.Денісова // Зб-к мат-в XV Міжнарод. науково-практич. конференції «Актуальні питання реформування правової системи України», м. Луцьк, 1-2.06. 2018. - Луцьк: СНУ, 2018. - С.122-124.
} 
скасування рішення або визнання незаконними вчиненої дії чи бездіяльності останнього (ч. 3 ст. 313 КПК) [14, с. 17]. На нашу думку, ця підстава є коректною, адже підставою для скасування рішення прокурора вищестоящим прокурором чи слідчим суддею $є$ його незаконність чи необгрунтованість. Не повинен залишатися керівником досудового розслідування прокурор, який при цьому порушує своїми діями чи бездіяльністю норми КПК, іншого законодавства.

К. Следняєва вважає найбільш дискусійними та суперечливими випадки заміни прокурора на підставі ч. 2 ст. 341 КПК України, а саме у разі відмови прокурора вищого рівня у погодженні обвинувального акта зі зміненим обвинуваченням, клопотання про висунення додаткового обвинувачення чи початок провадження щодо юридичної особи або постанови про відмову від підтримання державного обвинувачення. Фактично спостерігається обмеження самостійності прокурора та порушення його права діяти відповідно до свого внутрішнього переконання [6, с. 179]. Наша точка зору відрізняється від наведеної, оскільки законодавець через погодження ініціатив прокурора-обвинувача вищестоящим прокурором встановлює гарантію від можливих помилок, зловживань при підтриманні обвинувачення чи відмові від нього. У випадку, коли прокуроробвинувач наведе об'єктивно переконливі аргументи власної позиції, вкаже на норми законодавства, практику ЄСПЛ, ВС, які може бути порушено діями прокурора, то підстав для відмови його ініціативам немає. Якщо аргументи припускають різну інтерпретацію (наприклад, щодо недостатності обвинувальних доказів щодо обвинуваченого), то рішення вищестоящого прокурора буде дискреційним і грунтуватиметься на його фаховій оцінці позиції підлеглого прокурора та інших обставин кримінального провадження. При усуненні прокурора від підтримання обвинувачення саме його сформоване внутрішне переконання є головним мотивом заміни іншим прокурором. Адже замінений прокурор у такий спосіб не примушується діяти всупереч власному переконанню за наказом вищестоящого прокурора.

Останній пункт наведеного переліку підстав для заміни прокурора (інші поважні причини, що унеможливлюють участь прокурора у кримінальному провадженні (ч.3 ст. 37 КПК) має цілком дискреційний характер. О. В. Єні оцінила його як виправданий [20, с. 295]. А. В. Лапкін, О. О. Шпак це положення КПК сприймають критично, вважаючи, що воно відкриває простір для довільного тлумачення, посилання на «внутрішню необхідність» у діяльності органу прокуратури, що дозволяє втручатися у роботу прокурорів $[4$, с. $87 ; 21$, с. 330]. Ми вважаємо останню позицію слушною і для коректного застосування, більшої вищначеності аналізованої підстави для заміни прокурора iї слід викласти у наступній редакції: «інші поважні причини, що унеможливлюють участь прокурора у кримінальному провадженні, підтверджені конкретними фактами, які їх доводять».

Наведений вченими достатньо розгорнутий перелік підстав для заміни прокурора все ж потребує доповнення. Заміна прокурора також відбувається при передачі кримінального провадження для об'єднання із іншими через їх зв'язок - за рішенням Директора НАБУ та за погодженням із прокурором Спеціалізованої антикорупційної прокуратури (абз. 3 п. 5 ч.3 ст. 216 КПК) або за рішенням прокурора, який здійснює нагляд за досудовим розслідуванням, у разі неможливості виділення цих матеріалів в окреме провадження (ч. 10 ст. 216 КПК) чи з інших підстав для об'єднання чи виділення проваджень, які підслідні різним органам розслідування чи різним територіальним підрозділам в межах одного органу розслідування (ст. 217 КПК). Заміна прокурора відбувається у разі, якщо буде встановлено, що іншим слідчим органу досудового розслідування або слідчим іншого органу досудового розслідування раніше розпочато кримінальне провадження щодо того ж кримінального правопорушення, оскільки слідчий повинен передати наявні у нього матеріали та відомості відповідному слідчому, повідомивши про це прокурора (ч. 4 ст. 218 КПК). Такі випадки закономірно обумовлюють заміну прокурора без порушення правила про його незмінність .

За слушним зауваженням К. Следняєвої однією 3 непередбачених законодавцем причин заміни одного процесуального керівника іншим є надмірна завантаженість прокурорів [6, с. 179]. Як не парадоксально, такий стан зумовлений дією самого правила про незмінність прокурора, на що вказав М. Гошовський. Він наводить статистичні дані станом на 2013 р. про середнє навантаження на прокурорів у обсязі 70 проваджень на місяць, а у великих містах і обласних центрах -- як правило, від 100 до 200 проваджень [22, с. 72-73]. За узагальненням практики К. Следняєвою встановлено, що середнє навантаження на прокурорів органів прокуратури міста Києва у 2015 р. складало 103 кримінальні провадження на особу, у 2016 р. - 202, на кінець 2017 р. - 270. Крім того, з урахуванням різного професійного рівня співробітників прокуратури, максимальне навантаження на одну особу може досягати 600 і більше кримінальних проваджень [6, с.179]. Цілком зрозуміло, що за такого стану організації діяльності прокуратури забезпечити норму про незмінність прокурора не реально. Тому, як видається, прокурорська практика пішла шляхом створення груп прокурорів практично у всіх 
кримінальних провадженнях, що дозволило відповідно до ч. 1 ст. 37 КПК формально виконувати норму про незмінність прокурора. Ми поділяємо позицію науковців, які оцінюють таку тенденцію практики як некоректну, оскільки створення груп процесуальних керівників у ч. 1 ст. 37 КПК України передбачено як виняток із загального правила індивідуального керівництва досудовим розслідуванням [23, с. 82]. Такий висновок підтверджується нормами Порядку організації діяльності прокурорів і слідчих органів прокуратури у кримінальному провадженні, затв. наказом ГП України 28 березня 2019 року № 51 [17], у яких передбачено, що групи прокурорів повинні створюватися у провадженнях про кримінальне правопорушення, вчинені у складі організованої групи чи злочинної організації (п. 3 розд. III), у складному кримінальному провадженні (п. 2 розд. IV) [24].

На практиці такий виключний інструмент підвищення ефективності діяльності органів прокуратури у кримінальному провадженні став використовуватись як «механізм підстраховки» прокурора, який з тих чи інших причин не може бути присутнім у судовому засіданні. Так, 78\% опитаних процесуальних керівників вказали, що групи прокурорів створюються у кожному кримінальному провадженні, ще $16 \%$ - у більшості проваджень. Однак цей механізм є недостатньо ефективним, адже у будь-якому разі вся відповідальність покладена на старшого групи прокурорів, а всі інші члени групи, зазвичай, виявляються необізнаними з матеріалами конкретного кримінального провадження та ходом досудового розслідування. За результатами опитування таку позицію підтримали і самі процесуальні керівники [23, с. 82]. Вирішення цієї проблеми ми вбачаємо у визначенні адекватних нормативів максимального навантаження на прокурора на одиницю часу. Очевидно, що керівництво органів прокуратури також бачить лише таке розв'язання проблеми перевантаженості прокурорів, що підтверджує наказ ГП України «Про створення робочої групи 3 питань розробки порядку вимірювання та регулювання навантаження на прокурорів» від 05.03.2020 р. № 124. Сподіваємося, невдовзі буде знайдено виважений підхід до цієї проблеми .

Висновки. Дотримання правила про незмінність прокурора забезпечує його обізнаність із фактичними обставинами кримінального правопорушення, володіння доказовою базою, що є основою підвищення ефективності прокурора як суб'єкта підтримання публічного обвинувачення та представництва у суді та підставою посилення його відповідальності за посадову діяльність.

Період кримінального провадження, протягом якого прокурор має бути незмінним, розпочинається із моменту призначення прокурора як процесуального керівника досудовим розслідування окремою постановою, яка має виготовлятися на офіційному бланку і містити підпис керівника органу прокуратури. Правило про незмінність прокурора передбачає його участь як суді першої інстанції, так і у контрольних судових стадіях. Проте, виходячи із мотивів процесуальної економії, чинний КПК дозволяє участь вищестоящих прокурорів у судових засіданнях судів апеляційної, касаційної інстанцій.

Науковий аналіз змісту КПК дає підстави для визначення дуже широкого, фактично необмеженого кола підстав для заміни прокурора, що потребує конкретизації у частині оціночних понять. Для коректного застосування найбільш узагальненої підстави для заміни прокурора (ч. 3 ст. 37 КПК) запропоновано викласти ऑii у наступній редакції: «інші поважні причини, що унеможливлюють участь прокурора у кримінальному провадженні, підтверджені конкретними фактами, які їх доводять». Наведений вченими достатньо розгорнутий перелік підстав для заміни прокурора все ж потребує доповнення. Норми абз. 3 п. 5 ч.3 ст. 216, ч. 10 ст. 216, ст. 217 , ч. 4 ст. 218 КПК обумовлюють заміну прокурора без порушення правила про його незмінність .

Норма про незмінність прокурора у кримінальному провадженні масово порушується через надмірно велике збільшення обсягу його роботи. Вирішення цієї проблеми ми вбачаємо у визначенні адекватних нормативів максимального навантаження на прокурора. Розповсюджена практика створення груп прокурорів тільки маскує, а не вирішує проблему їх перевантаженості і не забезпечує мету запровадження правила про незмінність прокурора у кримінальному провадженні.

\section{Дюерела та література}

1. Рекомендації Робочої групи «Перспективи співробітництва України та ЄС у сфері юстиції, свободи та безпеки» щодо реформування кримінально-процесуального законодавства України [Електронний ресурс]. Режим доступу: http://do.gendocs.ru/docs/index-346105.html.

2. Пояснювальна записка до проекту Кримінального процесуального кодексу України [Електронний ресурс]. - Режим доступу: http://wl.cl.rada.gov.ua/pls/ zweb2/webproc4_1?pf3511 =42312.

3. Кримінальний процесуальний кодекс України [Електронний ресурс]. - Режим доступу: https://zakon.rada.gov.ua/laws/show/4651-17\#Text. 
4. Лапкін А. В. Принцип незмінності прокурора у кримінальному провадженні / А. В. Лапкін // Наук. вісник ХДУ. Юридичні науки. - 2015. - Вип. 2. - С. 85-89

5. Шульган I. I. Процесуальне керівництво досудовим розслідуванням як окрема функція органів прокуратури / I. І. Шульган // Вісник Національного університету «Львівська політехніка». Юридичні науки. - 2016. - № 837. - C. $516-520$

6. Сляднєва К. Самостійність та незмінність як диспозитивні засади діяльності прокурора у кримінальному провадженні / К. Сляднєва // Национ. юридич. журнал: теория и практика. - 2018. - Апрель. - С. 176-180.

7. Михайлю А. Організаційно-правові засади процесуального нагляду за дотриманням законності на стадії досудового розслідування / А. Михайлюк // Підприємництво, господарство і право. - 2019. - № 6.- С. 281-286.

8. Кримінальний процесуальний кодекс України: науково-практичний коментар у 2 т. / О.М.Бандурка, Є.М. Блажівський, Є. П. Бурдоль та ін. - Х.: Право, 2012. - Т. 1. - 768 с.

9. Сакал В. М. Місце та роль прокурора - процесуального керівника в організації досудового розслідування В. М. Сакал // Науковий вісник НАВС. - 2015. - № 2. - С. 41-51.

10. Толочко О. Гуманізація процесуального статусу прокурора в кримінальному провадженні / О. Толочко // Юридичний вісник. - 2014. - № 5. - С. 140-145.c.

11. Чорноусько М.В. Здійснення прокурором процесуального керівництва досудовим розслідуванням: теорія та практика: монографія / М. В. Чорноусько. - К.: Алерта, 2017. - 294 с.

12. Кахновець С. Реалізація дискреційних повноважень прокурора при здійсненні процесуального керівництва досудовим розслідуванням / С. Кахновець // Підприємництво, господарство і право. - 2017. - № 10. - С. 220222.

13. Туманянц А. Р., Говорун Д. М. Окремі аспекти реалізації прокурора в кримінальному провадженні / А. Р. Туманянц, Д. М. Говорун // Порівняльно-аналітичне право. - 2016. - №4. - С.c. 256-258.

14. Д'ячков Д. С. Принципи діяльності прокуратури у кримінальному провадженні / Д. С. Д’ячков // Науковий вісник УжНУ. Серія Право. - 2017. - Випуск 43, том 3. - С.c. 13-18.

15. Постанова ККС ВС від 17.12.2019 р. у справі № 235/6337/18 [Електронний ресурс]. - Режим доступу: http://www.reyestr.court.gov.ua/Review/86468617.

16. ККС висловився щодо оформлення рішення про визначення прокурора чи групи прокурорів у кримінальному провадженні [Електронний pecypc]. - Режим доступу: https://ukrainepravo.com/lawpractice/practice_court/kks-vyslovyvsya-shchodo-oformlennya-rishennya-pro-vyznachennya-prokurora-chy-grupyprokuroriv-u-krym/

17. Порядок у організації діяльності прокурорів і слідчих органів прокуратури у кримінальному провадженні, затв. Наказом ГПУ від 28 березня 2019 p. № 51 [Електронний ресурс]. - Режим доступу: https://zakon.rada.gov.ua/laws/show/z0363-19\#Text

18. Положення про порядок ведення Єдиного реєстру досудових розслідувань, затв. Наказом ГПУ від 06.04.2016 p. № 139 [Електронний ресурс]. - Режим доступу: https://zakon.rada.gov.ua/laws/show/z0680-16\#Text.

19. Руденко М. В. Процесуальне керівництво досудовим розслідуванням як нова функція прокуратури України: поняття, зміст і структура / М. В. Руденко // Науковий часопис Національної академії прокуратури України, 2014. - № 1. - C. 160-168.,

20. Єні О.В. Актуальні питання заміни прокурора у кримінальному провадженні / О. В. Сні // Форум права. - 2013. - № 1. - C. 294-299.

21. Шпак О. О. Особливості організації роботи керівника прокуратури з процесуального керівництва / О.О.Шпак // Часопис Київ. ун-ту права. - 2015. - № 2. - С. 328-332.

22. Гошовський М. Роль прокурора на стадії досудового розслідування // Слово Національної школи суддів. 2013. - № 4. - С.71-75.

23. Белоусов Ю. Прокурор: керує? наглядає? розслідує? Звіт за результатами дослідження «Роль прокурора на досудовій стадії кримінального процесу» / Ю. Белоусов, В. Венгер, В. Мітько, А. Орлеан, В. Сущенко, В. Яворська; за заг. ред. Ю. Бєлоусова -К.: СТ-Друк, 2017. - 268 с.

24. Критерії визначення складності провадження викладено у п. 2 розд. IV Порядку організації діяльності прокурорів і слідчих органів прокуратури у кримінальному провадженні, затв. Наказом ГПУ від 28 березня 2019 p. № 51 .

Крикунов А., Денисова Г. Несменяемость прокурора в уголовном производстве. Рассмотрены правовое обеспечение и научные подходы к несменяемости прокурора в уголовном производстве. Несменяемость прокурора как правовой и функциональный признак его статуса в уголовном производстве обеспечивает его самостоятельность, эффективность и, вместе с этим, усиливает его ответственность. Системный анализ норм Уголовного процессуального кодекса (УПК) Украины относительно участия прокурора в уголовном производстве указывает на существование значительного количества оснований для замены прокурора, которые требуют конкретизации в части оценочных понятий. Отдельные основания для замены прокурора носят дискреционный характер, что создает риски ошибок при их применении. Такое основание для замены прокурора в уголовном производстве, как «другие уважительные причины, которые делают невозможным участие прокурора в уголовном производстве» (ч.3 ст. 37 УПК Украины) имеет полностью дискреционный характер. 
Поэтому для корректного правоприменения эту норму следует дополнить словосочетанием «Подтвержденные конкретными фактами, которые их доказывают». Период уголовного производства, в течении которого прокурор должен быть неизменным, начинается с момента назначения прокурора как процессуального руководителя досудебным расследованием отдельным постановлением, которое должно изготавливаться на официальном бланке и содержать подпись руководителя органа прокуратуры. Правило о неизменности прокурора предусматривает его участие как в суде первой инстанции, так и в контрольных судебных стадиях. Однако, исходя из мотивов процессуальной экономии, действующий УПК позволяет участие вышестоящих прокуроров в судебных заседаниях судов апелляционной, кассационной инстанций. Норма о неизменности прокурора в уголовном производстве массово нарушается из-за чрезмерного увеличение объема его работы. Распространенная практика создания групп прокуроров только маскирует, а не решает проблему их перегруженности и не обеспечивает цель введения правила о неизменности прокурора в уголовном производстве. Решение этой проблемы мы видим в определении адекватных нормативов максимальной нагрузки на прокурора.

Ключевые слова: прокурор, несменяемость, уголовное производство.

Krykunov O., Denisova G. Irremovability of the Prosecutor in Criminal Proceedings. The article highlights the issues of legal support and scientific approaches to the irremovability of the prosecutor in criminal proceedings. The irremovability of the prosecutor as a legal and functional feature of his status in criminal proceedings ensures his independence, efficiency, and at the same time, personifies his responsibility. A systematic analysis of the provisions of the Criminal Procedure Code (CPC) of Ukraine on the participation of the prosecutor in criminal proceedings indicates the existence of a significant number of grounds for the replacement of the prosecutor, which require specification in in part of evaluative notions. Some grounds for replacing a prosecutor are discretionary, which creates risks of errors in their application. The ground for replacing a prosecutor in criminal proceedings, which reads «other valid reasons that make it impossible for a prosecutor to participate in criminal proceedings» (Part 3 of Article 37 of the CPC of Ukraine), is quite discretionary. It should be supplemented with the statement «confirmed by specific facts that prove them» for correct use. The period of criminal proceedings, during which the prosecutor must be unchanged, begins from the moment when the prosecutor is appointed as the procedural head of the pre-trial investigation by a separate resolution, which must be made on an official form and signed by the head of the prosecutor's office. The rule about the unchanging of the prosecutor provides for his participation both in the court of first instance and in the control court stages. However, based on the motives of procedural economy, the current CPC allows the participation of higher prosecutors in court hearings of appellate and cassation courts. The norm of the prosecutor's unchanging in criminal proceedings is being violated very often because of an excessive increasing in the volume of his work. We see the solution to this problem in determining adequate standards for the maximum burden on the prosecutor. The common practice of creating groups of prosecutors only masks, but does not solve the problem of their congestion and does not provide the purpose of introducing a rule on the unchanging of the prosecutor in criminal proceedings.

Key words: prosecutor, irremovability, criminal proceedings. 